\title{
CYANOBACTERIA AND ALGAL FLORA OF WADI EL- TAAL DESERT, ABU-ZENIMA AREA, SOUTH SINAI, EGYPT.
}

\author{
A. F. Hamed \\ Botany Department, Faculty of Science, Ain shams University, Abbassia, Cairo, \\ Egypt. \\ e-mail:zadel61@yahoo.com
}

\begin{abstract}
Cyanobacteria and algal flora of Wadi El-Taal in Abu-Zenima area have been studied by the georeferenced field survey using the Global Positioning System. Twenty one Cyanobacteria and algal taxa were identified in this investigation. The lentic habitats of El-Diesa Spring favoring the dominancy of thick mat structures of Cyanobacterial taxa of Hammatoidea simplex, Oscillatoria foreaui, Gloeocapsa decorticans and Gloeocapsa gelatinosa. In addition, the yellowish green colored algal filamentous mat of Rhizoclonium was recorded as a dominant green taxon overgrown by the epiphytic diatom of Mastogloia braunii. The lotic habitats of El-Gowisa Spring revealed the abundancy of the cyanobacterial mat of Oscillatoria salina. The physico-chemical parameters, in particular the alkaline $\mathrm{pH}$, high salinity and the lower content of phosphorus of water and soil may be contributed in the dominancy of Cyanobacteria in this area. Three taxa of Oscillatoria were identified and added to the updated list of Cyanobacteria of Egypt as new records.
\end{abstract}

\section{INTRODUCTION}

Studding of the algal flora of desert environment is of great importance, since its growth and metabolites making soil crusts favoring the appearance of richest microflora that have led to the formation of ecological, physiological and taxonomical studies (Evans and Johansen, 1999; Lewis and Flechtner, 2002; Hawkes and Flechtner, 2002).

Algal communities inhabiting arid and semiarid environment, where water and nutrients are limited. The source of water in these habitats is mainly from the seepage of the underground water through a fault in the earth crust (Swanberg et al., 1984).

Although intensive investigations have been carried out dealt with desert algal flora of different geographical territories in Egypt (Kobbia and ElBatanouny, 1975 in Wadi El-Natrun; Shaaban and El-Habibi, 1978 in Kharga Oasis; Hamouda, 1981 in Northern Coastal Desert; Salama and Kobbia, 1982 in Lybian Desert; Kobbia, 1985 in limestone desert of Cairo-Suez Road; Shaaban, 1985 in Siwa Oasis; Kobbia and Shabana, 1988 in Bahariya Oasis; El-Awamri et al., 1996 in Saint Catherine region; Shaaban and Hamed, 1997 in El-Arish Valley of North Sinai; Shaaban et al., 1997 in Hammam Faroun Spring, South Sinai; El- 
Otify and Mahalel, 2000 in Wadi Allaqi South Eastern Desret; Shaaban et al., 2000 in Burg El-Arab; Hamed, 2001 in Wadi Gharandel of Southwest Sinai, Ibrahim, 2002 in Wadi Araba Eastern Desert), no particular attention focused on the algal flora inhabiting Wadi El-Taal desert which is the aim of this study.

\section{Materials and Methods}

Wadi El-Taal is a semi-arid part of the south-west Sinai which lies in Abu-Zenima area (Fig. 1). It lies between latitude $29^{\circ} 07^{\prime} 30$ and $29^{\circ} 10^{\prime} 00 \mathrm{~N}$ and longitude $33^{\circ} 02^{\prime} 00$ and $33^{\circ} 13^{\prime} 00$ E. It contains wetlands along Suez Gulf shoreline. The hydro-geological formation of the two springs (El-Diesa Spring , El-Gowaisa Spring), resulting in the persistence of water in Wadi El-Taal desert (Swanberg et al., 1976). Generally, salts appear to be concentrated by a combination of some factors: gushing of water from the main spring, rate of evaporation by solar heating and a lack of rain (Swanberg et al., 1984).

Algal samples were collected from the two springs of Wadi El-Taal (Fig. 2), during the expedition of 25 March, 2003.

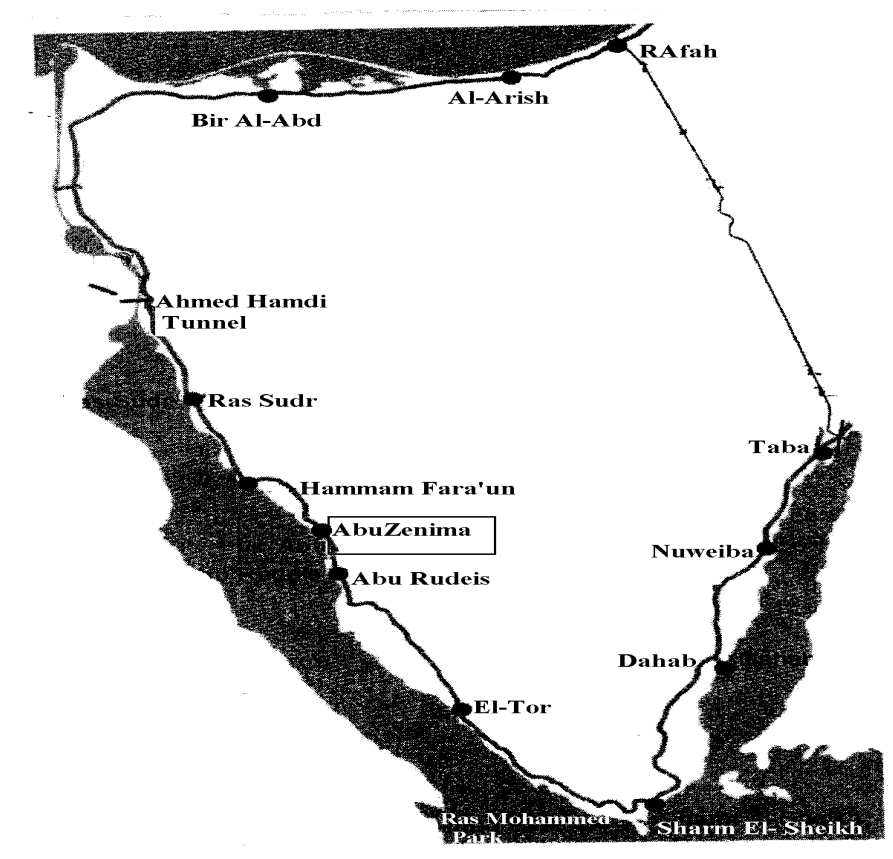

Fig 1: Major cities of Sinai Peninsula showing the locality of Abu Zenima 


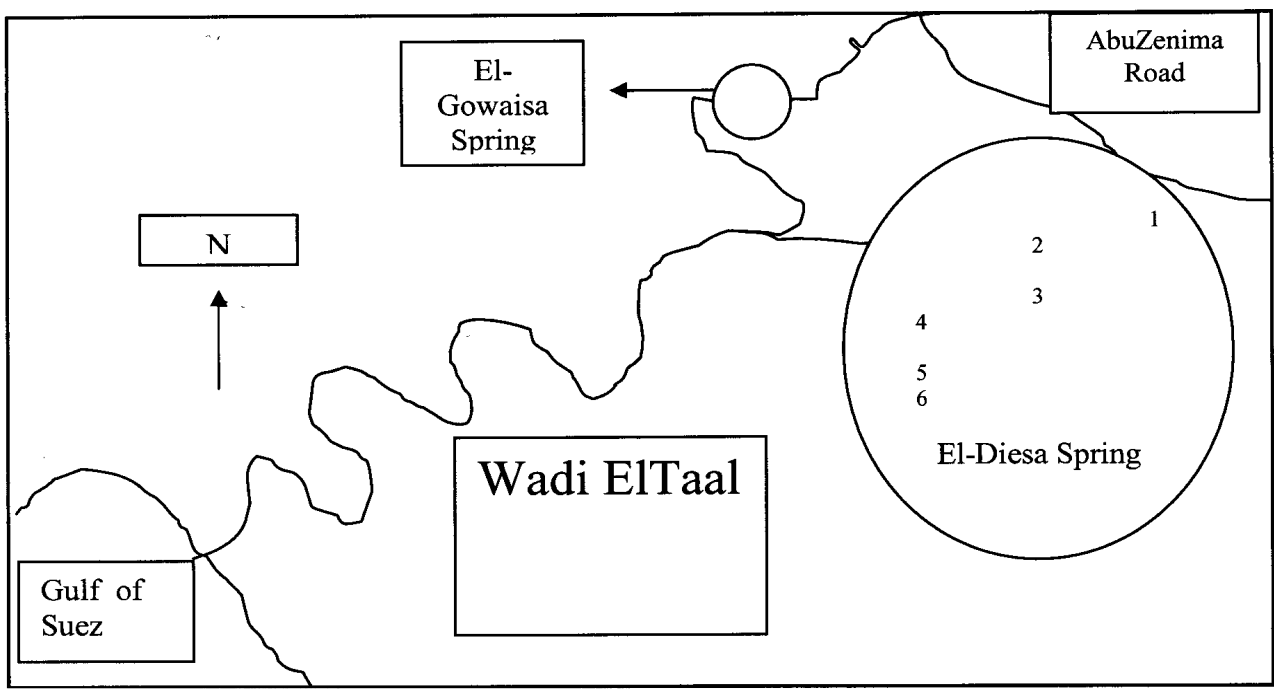

Fig.2. Schematic plan of Wadi El-Taal showing El-Diesa Spring and ElGowaisa Spring.

The geographical localities of stations were determined by the Global Positioning System (Garmin $12 \mathrm{X}$ ) which receiving signals from at least seven satellites to give an accurate longitudes and latitudes of the investigated stations (Table 1).

Table 1. Geographical localities of samples collected from El-Deisa Spring and El-Gowaisa Spring.

\begin{tabular}{|c|c|}
\hline Samples of El-Diesa Spring & GPS readings \\
\hline Station 1 & Latitude (N) $29^{\circ} 09^{\prime} 594 \&$ Longitude (E) $33^{\circ} 04^{\prime} 593$ \\
\hline Station 2 & Latitude (N) $29^{\circ} 09^{\prime} 594 \&$ Longitude (E) $33^{\circ} 04^{\prime} 593$ \\
\hline Station 3 & Latitude (N) $29^{\circ} 09^{\prime} 567$ \& Longitude (E) $33^{\circ} 04^{\prime} 557$ \\
\hline Station 4 & Latitude (N) $29^{\circ} 09^{\prime} 537$ \& Longitude(E) $33^{\circ} 04^{\prime} 514$ \\
\hline Station 5 & Latitude (N) $29^{\circ} 09^{\prime} 537 \&$ Longitude(E) $33^{\circ} 04^{\prime} 514$ \\
\hline Station 6 & Latitude (N) $29^{\circ} 09^{\prime} 537$ \& Longitude(E) $33^{\circ} 04^{\prime} 514$ \\
\hline $\begin{array}{l}\text { Sample of El-Gowaisa } \\
\text { Spring }\end{array}$ & Latitude (N) $29^{\circ} 09^{\prime} 386 \&$ Longitude (E) $33^{\circ} 03^{\prime} 427$ \\
\hline
\end{tabular}

The gushing of water from El-Diesa Spring constitutes lentic habitats in which different ecological appearance of mats and scums are formed on a sandloam substrate. On the other hand, water of El- Gowaisa Spring seeps in relatively lower rate where small ecological algal patches were found in salty-concentrated Egyptian J. of Phycol. Vol. 4(2), $2003 \quad$ - 205 - 
sand-loam substrate.

Removing of samples from its substrate were done easily by hand and preserved in $4 \%$ formalin. Temperature and $\mathrm{pH}$ of water were determined in the field by using a standard thermometer accurate to $0.1^{\circ} \mathrm{C}$ and digital $\mathrm{pH}$-meter (Cole Farmer USA) respectively. Soil samples were collected in clean air-tight plastic bags for determining its physico-chemical properties according to Jackson 1973. Identification of blue-green algae (Cyanobacteria) was based on Desikachary 1959; Anagnostidis and Komarek 1985, 1988; Komarek and Anagnostidis 1986. Cleaning of organic matter of diatom frustules was performed by Jouse et al., method (1949), and its identification was based on Hustedt (1957); Patrick and Reimer (1966, 1975) and Krammer and Lange-Bertalot $(1986,1988)$. Identification of green algae were guided by the key of Prescott (1961).

\section{Results and Discussion}

The results presented in Table 2, show that, water/soil reactions were mildly alkaline to alkaline as indicated by $\mathrm{pH}$ values which ranged from (7.7-7.8) to (8-8.2) in El-Diesa Spring and El-Gowaisa Spring respectively. According to soil classes (USDA, 1954), the soils of the two springs were highly saline as indicated by electric conductivity values of 39.5 mmohs for El-Diesa Spring and 43 mmohs for El-Gowaisa Spring.

Concerning the cationic composition, the soil saturated extracts for both studied springs were mostly dominated by $\mathrm{Ca}^{++}$followed by $\mathrm{Na}^{+}, \mathrm{Mg}^{++}$and $\mathrm{K}^{+}$ respectively. Among the anionic composition, the soil saturated extracts were characterized by the domination of $\mathrm{SO}_{4}^{--}$, followed by $\mathrm{Cl}^{-}$and then $\mathrm{HCO}_{3}{ }^{-}$. The values of available phosphorus (18 ppm for El- Diesa Spring, $12.5 \mathrm{ppm}$ for ElGowaisa Spring), revealed the deficiency of this element in this study area (according to its critical level reported by Lindsay and Norvel, 1978).

The microscopic identification of the natural assemblages of the biotopes of the study area indicated the presence of 21 Cyanobacteria and algal taxa (Table 3). Blue-green algae (Cyanobacteria) were represented by 14 taxa, from which 4 species were belonging to Family Chroococcaceae, 7 species and varieties were belonging to Family Oscillatoriaceae, 2 taxa were belonging to Family Nostocaceae and 1 taxon of Family Rivulariaceae. Six species and varieties of diatoms were recorded in this investigation mostly of pennatophycean type. The Chlorophyte of the filamentous forms of Rhizoclonium was identified to the level of the genus due to its vegetative structure was not bearing sexual stage which is the main discriminating feature used in the identification to the level of species or variety. 
Table 2 . Physico-chemical characteristics of water/soil samples of El-Diesa Spring and El-Gowaisa Spring of Wadi El-Taal.

\begin{tabular}{|c|c|c|}
\hline Element & El-Diesa Spring & El-Gowaisa Spring \\
\hline Water Temperature & $27^{\circ} \mathrm{C}$ & $29{ }^{\circ} \mathrm{C}$ \\
\hline $\mathrm{pH}$ of water/soil paste & $7.7 / 7.8$ & $8 / 8.2$ \\
\hline Soil electric conductivity & 39.5 millimohs & 43 millimohs \\
\hline \multicolumn{3}{|c|}{ Major cations and anions of soil paste in ppm } \\
\hline & El-Diesa Spring & El-Gowaisa spring \\
\hline $\mathrm{Na}^{+}$ & 260.92 & 280.1 \\
\hline $\mathrm{K}^{+}$ & 25.39 & 30 \\
\hline $\mathrm{Ca}^{++}$ & 583.76 & 590 \\
\hline $\mathrm{Mg}^{++}$ & 88.44 & 95.4 \\
\hline $\mathrm{CO}_{3}^{--}$ & 0 & 0 \\
\hline $\mathrm{HCO}_{3}^{-}$ & 85.36 & 86 \\
\hline $\mathrm{Cl}^{-}$ & 382.97 & 401.2 \\
\hline $\mathrm{SO}_{4}^{--}$ & 1754.80 & 1744.8 \\
\hline Available phosphorus & 18 & 12.5 \\
\hline
\end{tabular}

The lentic habitats of El-Diesa Spring favoring the appearance of thick mat structures of different colors. A yellowish-brown color mat of Cyanobacterium Hammatoidea simplex was found to be a dominant and abundant taxon which overgrown by a thin blue-green algal layer of Gloeocapsa gelatinosa. A scummy blue-green colored mat of Oscillatoria foreaui was recorded abundantly in most of the investigated samples. Chroococcean, dark blue-green mat of Gloeocapsa decorticans and Gloeocapsa gelatinosa was significantly represented the dominancy of their individuals among the recorded taxa. A yellowish-green filamentous mat of Rhizoclonium was favoring the growth of some epiphytic diatoms, particularly Mastogloia braunii.

The salty-concentrated substrate of El-Gowaisa Spring and the limited water gushing were contributed together for the lower algal diversity. The Cyanobacterial mat of Oscillatoria salina was found to be a characteristic and abundant taxon inhabiting the water patches that reflecting salt stress condition.

Generally, the physico-chemical characteristics of the wetlands of ElDiesa Spring and El-Gowisa Spring (in particular, alkaline $\mathrm{pH}$, high salinity, phosphorus limitation) were found to be the major contributing factors for the dominancy of the Cyanobacterial mats; this is in accordance with Rejmankova and Komarkova, 2000.

Three cyanobacterial taxa (Oscillatoria foreaui, Oscillatortia ornate var. crassa and Oscillatoria salina) were found to be new records for the Egyptian J. of Phycol. Vol. 4(2), $2003 \quad$ - 207 - 
Cyanobacterial flora of Egypt based on the updated list by Hamed, 2003 (in press).

Taxonomical remarks on new records based on their length and width dimensions are as follows:

1- Oscillatoria foreaui, its trichome of $9 \mu \mathrm{m}$ wide and $1.5 \mu \mathrm{m}$ long.

2- Oscillatoria ornata var. crassa, its trichome of $10.8 \mu \mathrm{m}$ wide and $5.4 \mu \mathrm{m}$ long. (Plate I, No. 1).

3- Oscillatoria salina, its trichome of $4.8 \mu \mathrm{m}$ wide and $2.7 \mu \mathrm{m}$ long. (Plate I, No. 2).

Table 3. Qualitative distribution of Cyanobacteria and algae of El-Diesa Spring and El-Gowaisa Spring of Wadi El-Taal, Abu-Zeniema during 25 March, 2003.

\begin{tabular}{|c|c|c|c|c|c|c|c|}
\hline \multirow[t]{3}{*}{ TAXA } & \multicolumn{6}{|c|}{ El-Diesa Spring } & \multirow[t]{2}{*}{$\begin{array}{c}\text { El-Gowaisa } \\
\text { Spring } \\
\end{array}$} \\
\hline & \multicolumn{6}{|c|}{ Stations } & \\
\hline & 1 & 2 & 3 & 4 & 5 & 6 & \\
\hline \multicolumn{8}{|c|}{ Cyanophyta/ Cyanobacteria } \\
\hline \multicolumn{8}{|l|}{ Family Chroococcaceae } \\
\hline Synechocystis pevalekii Ercegovic & & & + & & & & \\
\hline *Gloeocapsa decorticans ( A. Br.) Richter & & & + & + & + & + & \\
\hline *Gloeocapsa gelatinosa kütz. & + & + & + & & + & + & \\
\hline Gloeocapsa turgida (kütz) Hollerb. & & & & + & & & \\
\hline \multicolumn{8}{|l|}{ Family Oscillatoriaceae } \\
\hline Oscillatoria foreaui Fremy & + & + & + & + & + & & \\
\hline Oscillatoria nigroviridis Thwaites ex Gomont & + & + & + & & + & & + \\
\hline Oscillatoria okenii Ag. ex Gomont & + & & & & & & \\
\hline Oscillatoria ornate var. crassa Rao, C. B. & & & & + & + & + & \\
\hline *Oscillatoria salina Biswas & & & & & & & + \\
\hline Oscillatoria subbrevis Schmidle & & & & + & + & + & \\
\hline Oscillatoria subtilissima kütz. & & & & & + & + & \\
\hline \multicolumn{8}{|l|}{ Family Nostocaceae } \\
\hline Pseudanabaena catenata Lauterb. & + & & & & & & \\
\hline Cylindrospermum sp. & & & & & + & + & \\
\hline \multicolumn{8}{|l|}{ Family Rivulariaceae } \\
\hline *Hammatoidea simplex Wornochin & + & + & + & + & + & + & \\
\hline \multicolumn{8}{|c|}{ Bacillariophyta } \\
\hline \multicolumn{8}{|l|}{ Family Coscinodiscaceae } \\
\hline Cyclotella ocellata Pant & + & & & & & & + \\
\hline \multicolumn{8}{|l|}{ Family Fragilariaceae } \\
\hline Synedra nana Meist & & & & & & + & \\
\hline
\end{tabular}


Table 3. Continue

\begin{tabular}{|c|c|c|c|c|c|}
\hline \multicolumn{6}{|l|}{ Family Naviculaceae } \\
\hline Diploneis ovalis (Hilse) Cl. & & & & + & \\
\hline Mastogloia braunii Grum. & + & & & & + \\
\hline \multicolumn{6}{|l|}{ Family Epithemiaceae } \\
\hline Rhopalodia musculus (kütz.) 0. Müll. & & & & + & + \\
\hline \multicolumn{6}{|l|}{ Family Nitzschiaceae } \\
\hline Nitzschia obtuse var. kurzii Rabenh. ex Cleve et Moller & + & & & + & + \\
\hline \multicolumn{6}{|c|}{ Chlorophyta } \\
\hline Rhizoclonium $s p$ & & + & + & & \\
\hline
\end{tabular}

*Abundant taxa

\section{Plate I}

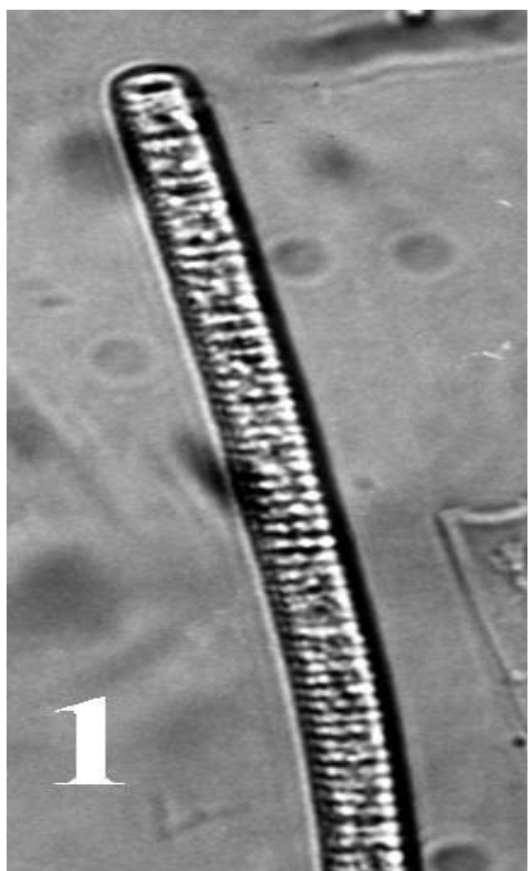

1- Oscillatoria ornate var. crassa

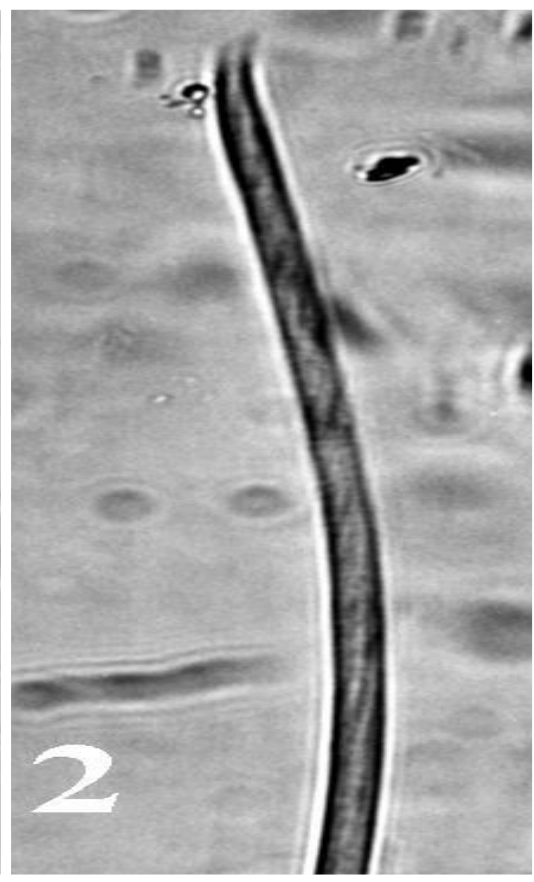

2- Oscillatoria salina

\section{References}

Anagnostidis, K. and Komarek, J. (1985). Modem approach to the classification system of cyanophytes. 1- Introduction. Arch. Hydrobiol Suppl. 71, 1/2 Algological studies, 38/39: 291 - 330 
Anagnostidis, K. and Komarek, J. (1988). Moderm approach to the classification system of cyanophytes. 3- Oscillatoriales. Arch. Hydrobiol. Suppl. 80 Algological Studies, 50/53: 327-372.

Desikachary, T. V. (1959). Cyanophyta. New Delhi. Indian Council Agricultural Research, 686 pp.

El-Awamri, A. A., Shaaban, A. S. and Hamed, A. F. (1996). Algae in Saint Catherine region (South Sinai) Egypt. Egyp. J. Bot., 36: 145-168.

El-Otify, A. M. and Mahalel, U. A. (2000). Ecological studies on the soil algae of Wadi Allaqi biosphere reserve area in south eastern desert, Egypt. Egypt. J. Phycol., 1:107-119.

Evans, R. D. and Johansen, J. R. (1999). Microbiotic crusts and ecosystem processes. Crit. Rev. Pl. Sci., 18: 183-225.

Hamed, A. F. (2001). Geographical distribution of aquatic and soil algae of Wadi Gharandel, Southwest Sinai, Egypt. Az. J. Microbiol., 53: 54-77.

Hamed, A. F. (in press). Survey of distribution and diversity of blue-green algae (cyanobacteria) in Egypt. Acta Botanica Hungarica.

Hamouda, M. S. A. (1981). Studies on the algal flora and its role in the northern coastal ecosystem of Egypt. M. Sc. Thesis, Faculty of Science, Cairo University, 185 pp.

Hawkes, C. V. and Flechtner, V. R. (2002). Biological soil crusts in xeric Florida shrubland: composition, abundance, and spatial heterogeneity of crusts with different disturbance histories. Microb. Ecol., 43: 1-12.

Hustedt, F. (1957). Die Diatomeenflora des Fluss-Systems der weser in Gebiet der Hansestadt Bremen. Abh. Naturw. Ver Bremen, 34: 181-440.

Ibrahim, B. M. I. (2002). Preliminary survey of microalgal soil crusts in a xeric habitats (Wadi Araba, eastern desert, Egypt). Egypt. J. Phycol., 2: 1-17.

Jackson, M. L. (1973). Soil Chemical Analysis. Printice Hall of India Private, New Delhi, 498 pp.

Jouse, A, P., Proschkina-Laverenko, A. I. and Sheshykova, V. C. (1949). Diatom Analysis Vol. 1 Pub. Geol. Liter. Leningrad, 339 pp.

Kobbia, I. A, (1985). Nitrogen-fixing blue-green algae of the semiarid regions along the gravel and limestone deserts of Cairo-Suez Road, Egypt. Sohag Pure and Appl. Sci. Bull. Fac. Sci. Egypt, 2:15.

Kobbia, I. A, and El-Batanouny, K. H. (1975). Studies on the algal flora of Egyptian soil. I. Different sites along a lake in the salines of Wadi ElNatrun. Pub. Cairo Univ.Herb.,6:61-72.

Kobbia, I. A. and Shabana, E. F. (1988). Studies on the soil algal flora of Bahraiya Oasis. Egypt. J. Bot., 31 (13): 23-43.

Komarek, J. and Anagnostidis, K. (1986): Modern approach to the classification system of cyanophytes. 2- Chroococcales. Arch. Hydrobiol. Suppl., Algological Studies, 73: 157-226.

Krammer, K. and Lange-Bertalot, H. (1986). Bacillariophyceae, Naviculaceae. 
Gustav Fisher Verlag. Stuttgart, New York, 876 pp.

Krammer, K. and Lange-Bertalot, H. (1988). Bacillariophyceae, Nitzschiaceae. Gustav Fisher Verlag. Stuttgart, New York, 821 pp.

Lewis, L. A. and Flechner, V. R. (2002). Green algae (Chlorophyta) of desert microbiotic crusts: diversity of North American Taxa. Taxon, 443-451.

Lindsay, W. I. and Norvel, W. A. (1978). Development of DTPA Soil Test. Soil Sci. Soc. Amr. Proc., 42: 1-8.

Patrick, R. and Reimer, C. W. (1966). The diatoms of the United States. Acad. Nat. Sci. Philadelphia. Monograph, 13(1): 1-688.

Patrick, R. and Reimer, C. W. (1975). The diatoms of the United States. Acad. Nat. Sci. Philadelphia. Monograph, 13(2,1): 1-213.

Prescott, G. W. (1961). Algae of the Western Great Lakes Area. Wm, C. Brown Publisher, Dubuque, Iowa, U.S. A., 977 pp.

Rejmankova, E. and Komarkova, J. (2000). A function of cyanobacterial mats in phosphorus - limited tropical wetlands. Hydrobiologia, 43(1-2); 135-153.

Salama, A. M. and Kobbia, I. A. (1982). Studies on the soil algal flora of Egyptian soils. II. Different sites of a sector in the Libiyan Desert. Egypt. J. Bot., 25: 139.

Shaaban, A. S. (1985). The algal flora of Egyptian Oases- II- On the algae of Siwa Oasis. Proc. Egyp. Bot. Soc., 4: 1-9.

Shaaban, A. S. and El-Habibi, A. M. (1978). The algal flora of the Egyptian Oases. I-The algal flora of Kharga Oasis. The Desert Inst. Bull., 28: 227232.

Shaaban, A. S. and Hamed, A. F. (1997). Fresh water algae of El-Arish Valley and its vicinity (North Sinai), Egypt. The Desert Inst. Bull., 47: 101-118.

Shaaban, A. S., Gebrell, H. M. and Hamed, A. F. (1997). Cyanobacteria of Haimnam Faroun hot spring. Egyp. J. Microbiol., 32: 49-57.

Shaaban, A. S., Hamed, A, F. and Hoda, M. A. (2000). Algal flora of Egyptian soils.1.The occurrence of cyanobacteria and algae in some habitats. Taeckholmia, 20(2): 159-171.

Swanberg, C. A.; Morgan, P.; Hennin, S. F.; Daggett, P. H.; Melic, Y. S. and El-Sherif, A. A. (1976). Preliminary report on the thermal springs of Egypt. Proc.Inter. Cong. on Thermal Waters, Geothermal Energy and Vulcanism of the Mediterranean Area. Natl. Univ. Athens, Greece, 2: 540-554.

Swanberg, C. A., Morgan, P. and Boulous, F. K. (1984). Geochemistry of the ground water of Egypt. Annals of the Geological Survey of Egypt., XIV: 127-150.

USDA (1954). Diagnosis and improvement of saline and alkali soils. USDA Handbook,No. 60, Riverside, Calif:, USA., 240 pp. 
بكتيريا الزرقاء المخضرة و فلورا الطحالب لوادى التال- منطقة ابو زنيمة ، جنوب \\ قسم النبات كلبة العلوم- جلمعة عبن شعس- العباسبه ـ القاهرة - مصدر.
}

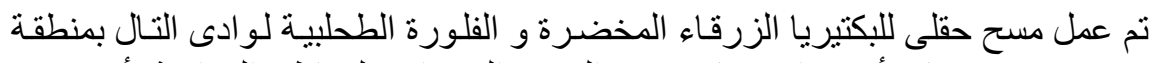

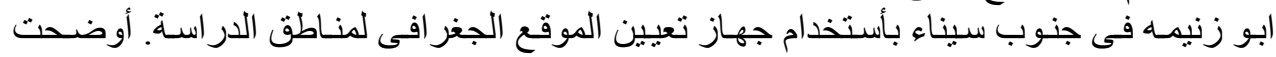

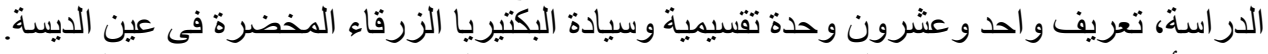

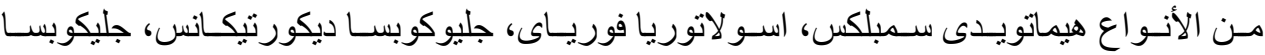

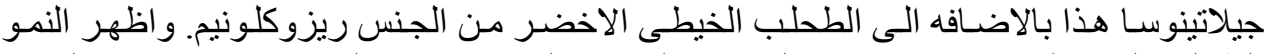

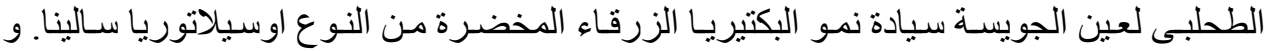

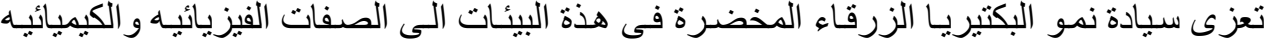

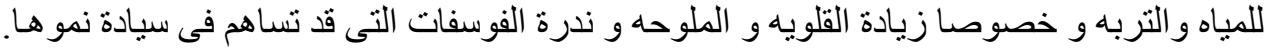

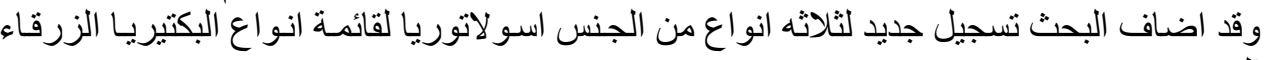

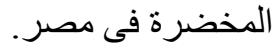

